\title{
Respons Pemerintah Lokal terhadap Ancaman Terorisme Global: Kasus ISIS di Kota Malang
}

\author{
Najamuddin Khairur Rijal
}

Universitas Muhammadiyah Malang

\begin{abstract}
ABSTRAK
Tulisan ini mengkaji mengenai bagaimana pemerintah lokal, dalam hal ini Pemerintah Kota Malang, merespons ancaman terorisme global Islamic State of Iraq and Syria (ISIS). Hasil penelitian lapangan ini menemukan bahwa dalam merespons ancaman ISIS, Pemkot Malang mengintegrasikan pendekatan persuasif dan represif. Pendekatan persuasif dilakukan dengan berbagai bentuk sosialisasi kepada masyarakat. Adapun pendekatan represif dengan melakukan penangkapan terhadap anggota ISIS yang telah terbukti melakukan tindak pidana berupa makar. Selanjutnya, dalam merespons ISIS, aktor publik di berbagai level dan aktor privat saling sinergis yang menunjukkan implementasi dari model hybrid security governance. Hybrid security governance tersebut sejalan dengan konsepsi local governance bahwa ancaman ISIS tidak dapat diselesaikan sendiri oleh pemerintah (aktor publik) sehingga membutuhkan keterlibatan aktor privat. Selain itu, respons tersebut sejalan dengan sikap pemerintah di level lebih tinggi yang menunjukkan the whole-of-government approach dan comprehensive approach dalam merespons ISIS sebagai ancaman bagi perdamaian dan keamanan dunia.
\end{abstract}

Kata-kata Kunci: ISIS, pemerintah lokal, security governance

This study analyzes how local government, in this case the Government of Malang City, responds to the threat of ISIS' global terrorism. The fieldresearch finds that the Government of Malang City integrates persuasive and repressive approaches. The persuasive approach focuses on promoting socialization to the local communities, while the repressive one is conducted through, for example, arresting ISIS affiliates who have been convicted of committing crime. In addition, public and private sectors collaboration is also promoted. They demonstrate the implementation of hybrid security governance model which is relevant to apply the comprehensive security governance in the context of both national and global responses to the ISIS' threat.

Keywords: ISIS, local government, security governance 
Tulisan ini merupakan hasil penelitian lapangan yang mengkaji mengenai bagaimana pemerintah lokal (local government) di Indonesia merespons ancaman terorisme globalIslamic State of Iraq dan Syria (ISIS). Sebagaimana dipahami, ISIS menjadi perhatian dunia internasional karena eksistensinya menimbulkan ancaman bagi perdamaian dan keamanan dunia melalui tindakan radikal dan anarkis yang dilakukannya. ISIS bercita-cita untuk mendirikan Negara Islam (Islamic State) dan menegakkan kekhalifahan Islam di Irak dan Suriah, namun dengan cara-cara kekerasan. Karena itu, Perserikatan BangsaBangsa (PBB) memasukkan ISIS organisasi teroris internasional (Organization of Islamic Cooperation 2015).

Guna mencapai tujuan politisnya, ISIS melakukan propaganda untuk mengajak seluruh umat Muslim melakukan jihad dan membantu perjuangan mereka dalam mendirikan Negara Islam. Propagandapropaganda tersebut disebarkan melalui beragam instrumen teknologi informasi dan komunikasi sehingga mampu menarik simpati umat Islam dari berbagai negara untuk melakukan jihad. Dengan demikian, ISIS bukan sekadar gerakan lokal di Irak dan Suriah, namun telah menjadi gerakan transnasional. Menurut Berger (2014), perkembangan ISIS menjadi gerakan transnasional tidak terlepas dari kemampuannya menggunakan teknologi informasi dan komunikasi via internet dan jejaring media sosial secara efektif.

Melalui instrumen teknologi informasi dan komunikasi itu ideologi ISIS tersebar ke berbagai negara, termasuk Indonesia. Sebagai respons, sejak 4 Agustus 2014 pemerintah Indonesia di bawah pemerintahan Presiden Susilo Bambang Yudhoyono (SBY) secara resmi melarang ISIS, baik secara formal maupun informal. Pemerintah Indonesia memandang bahwa ideologi ISIS bertentangan dengan ideologi Pancasila dan kondisi keberagaman yang ada di Indonesia (Martel 2014). Sikap pemerintah pusat tersebut selanjutnya direspons oleh pemerintah di level provinsi.

Provinsi Jawa Timur (Jatim), misalnya, mengeluarkan Peraturan Gubernur (Pergub) Nomor 51 Tahun 2014 tentang Larangan ISIS. Munculnya Pergub tersebut didasari karena wilayah Jatim dipandang sebagai "rahim" terorisme dan juga perkembangan paham revivalisme Islam (baik yang menempuh cara-cara moderat maupun radikal), termasuk ISIS. Hal itu sebagaimana diungkapkan Kepala Bakesbangpol Jatim Zainal Muhtadien (Sudarmojo 2014). Karenanya, menjadi menarik kemudian untuk menganalisis bagaimana respons pemerintah lokal di level kabupaten/kota dalam menyikapi hal itu, khususnya terkait 
ancaman ISIS. Perlunya menganalisis respons pemerintah lokal (local government) terhadap ancaman ISIS semakin signifikan karena belum ditemukan pada kajian atau penelitian terdahulu.

Berdasarkan penelusuran literatur yang dilakukan penulis, kajian terkait respons terhadap isu dan ancaman ISIS ini lebih banyak dilakukan pada level analisis global atau internasional, regional dan multilateral, serta level negara. Penelusuran literatur yang dilakukan penulis belum menemukan kajian terkait respons terhadap ancaman ISIS pada level pemerintah lokal, setidaknya dalam konteks Indonesia. Sehingga, terdapat celah empiris dan teoritik yang menjadikan hasil penelitian ini signifikan.

Pemerintah lokal yang menjadi objek penelitian adalah Pemerintah Kota (Pemkot) Malang. Malang menjadi salah satu titik yang dipantau untuk mencegah penyebaran ISIS (Jatimprov.go.id 2014). Selain itu, pada 20 Juli 2014 pernah digelar deklarasi dukungan terhadap ISIS. Beredar pula video seruan jihad yang menampilkan Salim Mubarak Attamimi yang disebut merupakan "panglima"ISIS yang berasal dari Kota Malang. Bahkan, pada 25 Maret 2015, tiga orang anggota ISIS ditangkap di Kota Malang. Hal ini menunjukkan fakta mengenai adanya jaringan ISIS di Kota Malang. Selanjutnya, penelitian dilakukan antara April hingga Mei 2015 dengan metode pengumpulan data melalui wawancara tidak terstruktur kepada narasumber.

\section{ISIS dan Gerakan Revivalisme Islam di Indonesia}

ISIS merupakan gerakan atau kelompok ekstremis yang dibentuk pada 9 April 2013 di bawah pimpinan Abu Bakar al-Baghdadi. Eksistensi ISIS dapat ditelusuri dari berdirinya Jamaat al-Tawhid wa-l-Jihad (JTWJ) pada 1999 di bawah pimpinan Abu Mus'ab al-Zarqawi. Kemudian berevolusi menjadi al-Qaida in Iraq (AQI) pada 2004, Majlis Shura alMujahedin (MSM) lalu Islamic State of Iraq(ISI) pada 2006, pada 2013 menjadi ISIS, dan pada 29 Juni 2014 menjadi Islamic State (IS).

Adapun definisi musuh bagi ISIS terdiri dari musuh internal (near enemy) dan musuh eksternal (far enemy) (The Meir Amit Intellegence and Terrorism Information Center 2014). Musuh eksternal atau musuh jauh adalah orang-orang Barat atau secara umum non-Muslim, sementara musuh internal atau musuh dekat adalah orang-orang Muslim yang bekerja sama dengan Barat atau kelompok lain selain dari pihak ISIS. Doktrin yang dimilikinya disebut takfiri (takfiriyya), yakni 
semua pihak yang berada di luar golongan mereka disebut sebagai kafir dan boleh dibunuh (Friedland 2014).

Paham ISIS kemudian dapat tersebar ke berbagai negara karena ISIS melakukan propaganda dengan menggunakan media sosial seperti Facebook, Twitter, serta Youtube. Selain itu, juga dengan menerbitkan Majalah Dabiq, serta memiliki Institut Produksi Media al-Furqan dan $\mathrm{Al}$ Hayat Media Center yang memproduksi CD, DVD, poster, pamflet, dan produk propaganda lain. Dalam konteks ini, ada dua jenis propaganda yang dilakukan ISIS (Mashuri 2014). Pertama, berupa ajakan kepada umat Islam di seluruh dunia untuk bergabung dengan ISIS atau dalam bahasa mereka "li nashrati al-Islam wa al-muslimin", memenangkan Islam dan kaum Muslim. Jenis kedua adalah dengan ancaman dan teror dengan menampilkan tindakan radikal yang mereka lakukan untuk menunjukkan eksistensinya terhadap musuh.

Selanjutnya dalam konteks Indonesia, hadirnya paham untuk mendirikan Negara Islam sejatinya bukanlah sesuatu yang baru (Azra 2005 dalam Boy 2008). Menurut juru bicara Badan Nasional Penanggulangan Terorisme (BNPT) Irfan Idris (dalam Prabowo 2015a), paham seperti ISIS merupakan paham yang telah berkembang lama di Indonesia. Hanya saja ISIS adalah sebutan baru dari perkembangan paham tersebut, tetapi secara ideologi cenderung sama. Hal yang sama dikemukakan mantan Kepala BNPT Ansyaad Mbai (dalam Kuwado 2015), yang menyebut bahwa gerakan ISIS bukanlah "barang baru" di Indonesia. ISIS hanya nama baru dengan formasi orang-orang lama. Menurutnya, gerakan untuk mendirikan Negara Islam di Indonesia sudah ada sejak kelahiran Indonesia, awalnya bernama Negara Islam Indonesia (NII) yang diusung oleh Darul Islam (DI) pimpinan Kartosoewirjo.

Menjelang dan setelah tumbangnya Orde Baru pada tahun 1998 kemudian memperlebar ruang gerak bagi eksistensi gerakan dan pahampaham yang memiliki cita-cita mendirikan Negara Islam (Wahid et al. 2009). Era Reformasi pasca Orde Baru menimbulkan perubahanperubahan substansial dengan hadirnya era kebebasan publik (demokrasi) dan menjadikan isu kembalinya khilafah menemukan momentumnya (Hidayat et al. 2014; Al-Makassary 2003). Berakhirnya rezim Orde Baru, menurut Boy (2008), sering kali dianggap sebagai titik di mana kelompok-kelompok Islam muncul kembali dalam sejarah Indonesia kontemporer. 
Fenomena tersebut antara lain dapat dilihat dari eksistensi Hizbut Tahrir Indonesia (HTI), Laskar Jihad (yang kemudian membentuk Forum Komunikasi Ahlus-Sunnah Waljama'ah/FKAWJ), Laskar Jundullah, Laskar Fisabilillah, Front Pembela Islam (FPI), Komite Persiapan Penerapan Syariah Islam (KPPSI), dan lainnya, selain Jamaah Islamiyah (JI) yang telah hadir sejak era 1990-an (kemudian menjadi Majelis Mujahidin Indonesia/MMI lalu Jamaah Ansharut Tauhid/JAT).Karenanya, keberadaan jaringan ISIS di Indonesia diduga tidak terlepas dari simpati serta dukungan dari kelompok/gerakan revivalisme Islam yang ada di Indonesia.Menurut mantan Wakil Kepala Badan Intelijen Negara (BIN) As'ad Said Ali (dalam Prabowo 2015b), ISIS telah memiliki jaringan di Indonesia bernama Jamaah Ansarul Daulat (JAD)yang merupakan gabungan dari sejumlah kelompok dan gerakan revivalisme Islam yang sebelumnya telah ada di Indonesia.

\section{Indikasi ISIS di Kota Malang}

Sebagaimana konteks Indonesia, eksistensi kelompok yang mengusung ide kebangkitan Islam di Kota Malang juga bukan sesuatu yang baru. Menurut catatan Bakesbangpol, indikasi paham-paham radikal di Kota Malang telah lama dipantau. Paham-paham itu telah menyatu dengan masyarakat dan bergerak "di bawah tanah" sehingga sulit dideteksi (Noermawan 2015). Kemunculan ISIS kemudian menjadi momentum bagi Pemkot Malang untuk secara tegas mengantisipasi ancaman paham-paham yang berpotensi memecah belah persatuan bangsa (Widianto 2015).

Dalam konteks Kota Malang, isu ISIS mulai muncul di permukaan bermula pada 15 Juli 2014. Beredar pamflet dan informasi di media sosial yang berisi undangan Ansharul Khilafah Jatim terkait kegiatan Sosialisasi dan Dukungan pada Daulah Islamiyah. Pamflet tersebut selain di-posting secara online juga disebarkan di beberapa kampus di Kota Malang. Acara tersebut digelar pada 20 Juli 2014 di Masjid Jami' Sulaiman Al Hunaishil di Dusun Sempu, Desa Gading Kulon, Kecamatan Dau, Kabupaten Malang, setelah rencana awal di Masjid Ibnu Sina, Kota Malang tidak mendapatkan izin dari pengurus masjid. 


\section{Gambar 1. Gambaran tentang Kegiatan Ansharul Khilafah Jatim}
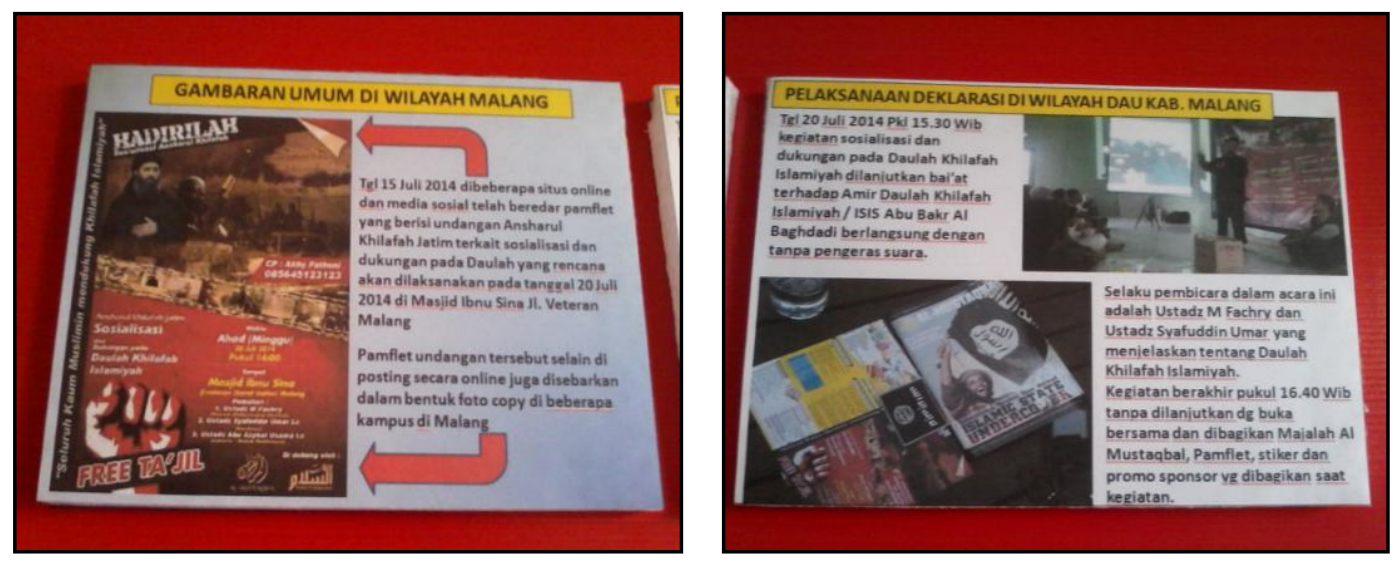

Sumber: Sat Intelkam Polresta Malang (2015)

Terlaksananya kegiatan tersebut kemudian menjadikan isu ISIS mengemuka di Kota Malang. Sekalipun kegiatan itu digelar di wilayah administratif Kabupaten Malang, namun menurut Kabid Integrasi Bangsa Bakesbangpol Kota Malang Tony Noermawan (2015), ada ketakutan tersendiri bahwa pasca deklarasi tersebut ISIS semakin menyebar, apalagi rencana awal akan digelar di wilayah Kota Malang.Selain itu, indikasi kehadiran ISIS di Kota Malang telah ada sejak awal 2014. Menurut informasi Intelijen (2015), pada awal $2014 \mathrm{di}$ sebuah lembaga pendidikan dan pesantren mahasiswa diketahui pernah berkibar bendera berlogo ISIS.

Tidak hanya itu, pada awal 2014 juga terdeteksi simpatisan ISIS di sebuah rumah penduduk di Kelurahan Sukoharjo, Kecamatan Klojen, Kota Malang. Rumah tersebut memasang bendera ISIS dan di jendela rumah ditempel stiker ISIS. Namun, pihak terkait berhasil melakukan pendekatan persuasif dan pemilik rumah bersedia melepas bendera dan stiker berlogo ISIS tersebut. Eksistensi jaringan ISIS di Kota Malang semakin terbukti dengan ditangkapnya tiga orang anggota dan jaringan ISIS pada 25 Maret 2015. Ketiga orang tersebut adalah Abdul Hakim Munabari (AHM), Helmi Alamudi (HA), dan Ahmad Junaidi (AJ). Ketiganya merupakan warga Kota Malang.

Munculnya beberapa indikasi keberadaan ISIS dan terutama pasca ditangkapnya anggota ISIS di Kota Malang menjadikan ISIS mendapat perhatian serius Pemkot Malang dan para stakeholders terkait. ISIS 
dipandang sebagai ancaman yang berpotensi mengganggu stabilitas keamanan daerah dan bertentangan dengan ajaran Islam mainstream yang dianut oleh mayoritas warga Kota Malang, karenanya segera direspons dengan serangkaian upaya.

\section{Eksistensi dan Ancaman ISIS di Kota Malang}

Pemkot Malang memandang eksistensi ISIS sebagai ancaman bagi integrasi bangsa dan persatuan umat serta mengganggu keamanan dan ketertiban masyarakat. Atas dasar itu, menurut Kepala Bagian Humas Pemkot Malang Nur Widianto (2015), sejak awal indikasinya, ISIS menjadi perhatian serius Pemkot Malang. ISIS dipandang sebagai bentuk radikalisme agama yang tidak sejalan dengan hakikat agama Islam yang cinta damai (Widianto 2015; Noermawan 2015; Askandar 2015).

Sementara itu, mengenai informasi dan pengetahuan Pemkot Malang terkait ISIS, PemkotMalang memiliki jejaring informasi intelijen yang diwadahi melalui Komunitas Intelijen Daerah (Kominda). Kominda merupakan komunitas yang menghimpun intelijen dari semua korps atau instansi yang memiliki intelijen di Kota Malang. Dalam hal ancaman ISIS, Kominda yang menjadi supplier informasi mengenai ISIS dan pergerakan jaringan serta pihak-pihak yang diindikasi menjadi bagian dari ISIS di Kota Malang.

Lebih dari pada itu, berdasarkan keterangan Noermawan (2015), informasi tentang pergerakan jaringan ISIS juga berasal dari keberadaan agen intelijen X. Agen intelijen X sengaja diminta masuk dan bergabung dengan pihak-pihak yang diindikasi berafiliasi dengan paham ISIS.Dengan demikian, informasi intelijen Kominda berasal dari dua arah, yakni informasi dengan memantau langsung pergerakan jaringan ISIS dan informasi dari agen intelijen yang menyusup di dalam jaringan ISIS itu sendiri.

Selain itu, Pemkot Malang juga menerima informasi dari aktor lain, seperti Forum Kerukunan Umat Beragama (FKUB), Nahdlatul Ulama (NU), dan Muhammadiyah. Ketua Tanfidziyah PCNU Kota Malang Isroqun Najah (2015) mengakui bahwa antara NU dan Pemkot Malang saling berbagi informasi. Begitupula FKUB yang memiliki tugas untuk membantu pemerintah dalam rangka mewujudkan kerukunan umat beragama selalu memberikan informasi kepada Pemkot mengenai kelompok-kelompok yang berpotensi menciptakan disintegrasi (Santoso 
2015). Sementara Muhammadiyah, menurut Sangadji (2015), juga terus menjalin komunikasi dengan Pemkot mengenai hal-hal yang mengganggu keamanan dan ketertiban masyarakat di Kota Malang.

Mengenai bagaimana jaringan ISIS dapat masuk ke Kota Malang, tidak ada informasi pasti. Apalagi karena pergerakan jaringan ISIS tidak nampak di permukaan serta masuk melalui paham-paham agama sehingga sulit untuk mendeteksi keberadaannya. Hal itu diakui oleh narasumber Intelijen (2015) bahwa berbicara mengenai gerakan terorisme, termasuk ISIS, maka berbicara tentang gerakan intelijen yang bersifat senyap (silent).

Masuknya paham ISIS di Kota Malang ditengarai dibawa oleh para kombatan atau mereka yang pernah melakukan perjalanan ke Irak atau Suriahlalu bergabung menjadi milisi ISIS. Hal itu dibuktikan dengan tiga orang anggota ISIS yang ditangkap di Kota Malang semuanya tercatat pernah berangkat jihad ke Suriah (Intelijen 2015). Hal senada diungkapkan Effendy (2015), bahwa umumnya kelompok terorisme di Indonesia, termasuk jaringan ISIS, dikembangkan oleh para "alumni" perang di Timur Tengah.

Selain itu, paham ISIS juga diduga masuk melalui persentuhannya dengan kelompok-kelompok rentan (Intelijen 2015). Kelompok rentan merupakan perkumpulan kelompok atau organisasi yang memiliki pemahaman mengenai perlunya kebangkitan Islam atau berafiliasi dengan suatu gerakan yang melakukan upaya ishlah (perbaikan atau reformasi) tertentu, atau pihak-pihak yang banyak terlibat dalam aktivitas dan kajian-kajian yang menginginkan revivalisme Islam dengan memandang perlunya penegakan syariat Islam dan pendirian Khilafah Islamiyah.

Sementara itu, menurut Najah (2015), Kota Malang dikenal sebagai Kota Pendidikan sehingga menjadi lokasi yang strategis dan potensial bagi penyemaian berbagai jenis paham, termasuk paham radikal. Terlebih lagi, wilayah teritorial Kota Malang yang terdiri dari lima kecamatan yang secara geografis letaknya saling berdekatan sehingga penyebaran informasi antar jaringan cenderung berlangsung cepat dan lalu lintas pergerakannya berlangsung mudah.Hal itu diperkuat oleh pernyataan Kepala Bakesbangpol Jatim Zainal Muhtadien (dalam Sudarmojo 2014) bahwa Kota Malang menjadi salah satu dari tujuh daerah yang terus dipantau terkait penyebaran berbagai jenis paham yang berpotensi mengganggu integrasi bangsa. 
Selain itu, keberadaan jaringan ISIS di Kota Malang juga tidak terlepas dari Salim Mubarak Attamimi atau Abu Jandal (Intelijen 2015). Salim disebut-sebut sebagai "panglima ISIS" dari Kota Malang. Berdasarkan catatan Kepolisian Malang, Salim bukanlah orang yang baru. Aktivitasnya di Kota Malang telah lama dipantau oleh intelijen dan pergerakannya telah terekam di Kepolisian. Tiga anggota ISIS yang ditangkap di Kota Malang disebut merupakan bagian dari jaringan Salim (Intelijen 2015).

\section{Gambar 2. Informasi tentang Salim Mubarak Attamimi}

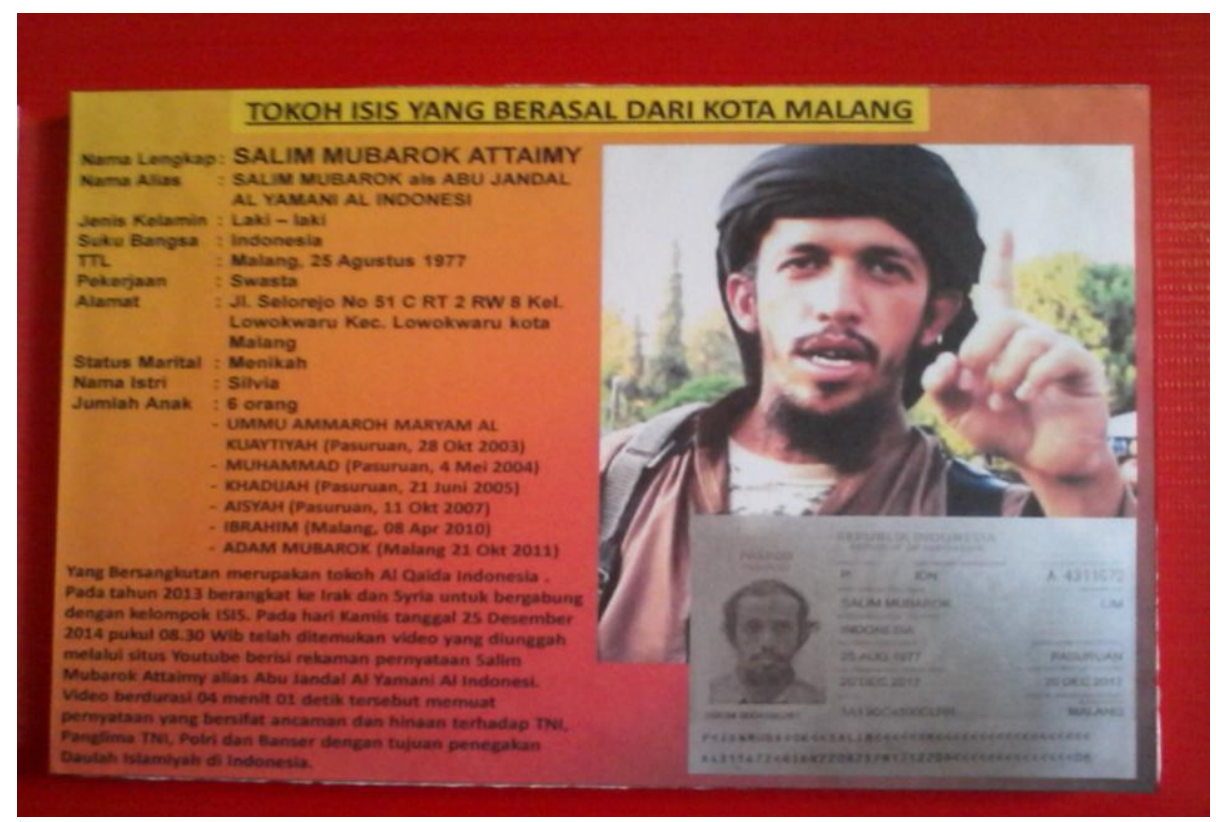

Sumber:Sat Intelkam Polresta Malang (2015)

\section{Respons terhadap Ancaman ISIS di Kota Malang}

Serangkaian indikasi keberadaan dan ancaman ISIS di Kota Malang kemudian segera direspons oleh Pemkot Malang. Penulis memilah isu ISIS di Kota Malangke dalam dua term waktu. Pertama, yakni pasca kegiatan sosialisasi dan deklarasi dukungan terhadap ISIS pada 20 Juli 2014. Kedua, pasca penangkapan tiga orang anggota ISIS pada 25 Maret 2015. Respons Pemkot Malang dalam kedua term waktu tersebut 
selanjutnya dapat dikategorikan ke dalam dua bentuk, yakni pendekatan persuasif dan represif. Bentuk upaya persuasif adalah melalui sosialisasi, dialog, himbauan, dan lainnya. Sementara upaya represif dalam bentuk penangkapan dan penegakan hukum oleh aparat keamanan.

Pemkot Malang melalui Bakesbangpol melakukan upaya counter attack dalam merespons terselenggaranya kegiatan sosialisasi dan deklarasi dukungan terhadap ISIS pada 20 Juli 2014. Counter attack tersebut dilakukan dengan menggelar Sosialisasi Penanaman Nilai-nilai Sejarah Kebangsaan pada 13 dan 18 Agustus 2014 dengan topik khusus perbincangannya mengenai ISIS dan dirangkaikan dengan Deklarasi Penolakan terhadap Keberadaan ISIS di Kota Malang. Tindak lanjut dari deklarasi tersebut adalah aparat kelurahan di seluruh kecamatan diwajibkan untuk melakukan sosialisasi kepada masyarakat dan waspada dini terkait keberadaan ISIS dan paham-paham lain yang bertentangan dengan NKRI.

\section{Gambar 3. Naskah Deklarasi Menolak Keberadaan ISIS di Kota Malang}

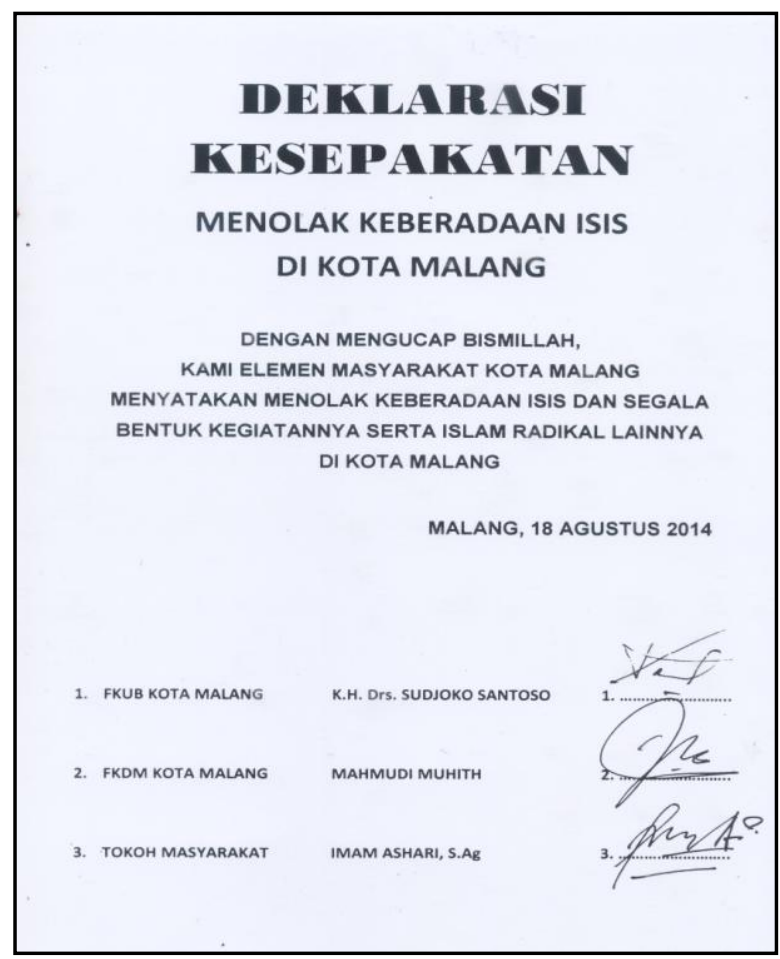

Sumber: Bakesbangpol Kota Malang (2015) 
Akan tetapi, sosialisasi dan deklarasi penolakan terhadap keberadaan ISIS yang digelar Pemkot Malang, menurut penulis, perlu dipandang hanya sebagai respons insidental. Artinya, respons itu muncul hanya ketika isu ISIS sedang hangat, yakni sekitar Juli-September 2014. Pendapat tersebut sejalan dengan pengakuan Noermawan (2015), bahwa dalam rentang waktu Oktober 2014-Maret 2015, jajaran Pemkot menganggap isu ISIS telah mereda. Persepsi tersebut menjadikan perhatian Pemkot Malang tidak lagi difokuskan pada upaya counter ISIS. Namun, ditangkapnya tiga orang anggota ISIS pada 25 Maret 2015 menunjukkan bahwa Kota Malang tidak bebas dari keberadaan paham dan jaringan ISIS, sekaligus menjadikan isu ISIS kembali mengemuka sehingga menuntut Pemkot lebih aktif dan responsif.

Sementara itu, penangkapan tiga anggota ISIS di Kota Malang menunjukkan adanya respons represif yang dilakukan. Tertangkapnya tiga orang itu tidak terlepas dari upaya proaktif yang dilakukan jajaran Pimpinan Daerah (Walikota, Kepolisian, Tentara Nasional Indonesia/TNI), yang selanjutnya dieksekusi oleh Detasemen Khusus (Densus) 88 sebagai aktor yang memiliki wewenang dalam hal penangkapan terhadap terduga teroris.Upaya proaktif yang dimaksud adalah dalam hal pengamanan wilayah yang dilakukan oleh aparat gabungan dari Kepolisian dan TNI dengan memantau seluruh wilayah Kota Malang (Noermawan 2015). Penangkapan tersebut juga tidak terlepas dari suplai informasi intelijen dalam Kominda. Berdasarkan informasi dari Satuan Intelijen dan Keamanan (Sat Intelkam) Polresta Malang dan Bakesbangpol, pihak-pihak yang ditangkap memang sudah lama diawasi pergerakannya. Mereka telah menjadi target intelijen selama beberapa bulan, terutama sejak Juli 2014 (Intelijen 2015; Noermawan 2015).

Selanjutnya, pasca penangkapan tiga anggota ISIS di Kota Malang mendorong Pemkot Malang bertindak cepat dalam merespons ancaman ISIS. Kenyataan itu mendorong upaya-upaya persuasif lebih diintensifkan (Widianto 2015). Sebagai bentuk respons, pemerintah melakukan silaturahmi, dialog, dan sosialisasi. Sehari setelah peristiwa penangkapan, Walikota Malang langsung melakukan kunjungan ke lokasi ditangkapnya AJ di Kelurahan Bumiayu, Kecamatan Kedungkandang untuk melakukan komunikasi dengan masyarakat dan menghimpun informasi mengenai aktivitas AJ. Selanjutnya, Kecamatan Kedungkandang merupakan salah satu kawasan yang menjadi fokus 
upaya pendekatan persuasif melalui sosialisasi untuk mencegah meluasnya paham dan jaringan ISIS.

Selanjutnya, pada 31 Maret 2015 dalam rangkaian peringatan Hari Jadi Kota Malang ke-101 juga digelar pertemuan yang mengumpulkan seluruh umat beragama di Kota Malang. Selain membincangkan kerukunan antar umat beragama dan kerukunan antar umat dalam satu agama (internal agama), juga secara khusus membahas tentang ancaman ISIS. Selain itu, merespons penangkapan anggota ISIS tersebut, pada 2 April 2015, Walikota memerintahkan untuk mengumpulkan masyarakat melalui setiap kelurahan untuk diadakan sosialisasi kepada RT/RW. Masyarakat juga diminta melaporkan apabila ada indikasi keberadaan ISIS di lingkungannya.

Pemkot Malang juga memiliki program Sambung Rasa untuk berkomunikasi dengan masyarakat setiap sekali dalam dua pekan ke berbagai wilayah di lingkup Kota Malang. Pada beberapa kesempatan tersebut, Walikota juga memberikan sosialisasi terkait upaya apa yang perlu dilakukan oleh masyarakat dalam mengantisipasi keberadaan paham dan jaringan ISIS di lingkungan mereka. Salah satu sasaran program Sambung Rasa di mana Walikota secara khusus membahas mengenai ancaman dan antisipasi keberadaan jaringan ISIS adalah di Kelurahan Gadingkasri, Kecamatan Klojen pada 5 April 2015.

Sayangnya, sekalipun kegiatan Sambung Rasa tersebut berlangsung rutin, namun penyampaian terkait ancaman ISIS dan upaya yang perlu dilakukan masyarakat dalam mengantisipasi keberadaan ISIS hanya bersifat insidental. Disebut insidental karena isu ISIS hanya dibahas secara khusus terutama pasca penangkapan tiga anggota ISIS di Kota Malang menjadi trending topic. Selebihnya, dalam kegiatan Sambung Rasa, Walikota dan jajarannya membahas isu-isu lain yang sedang hangat dan hal-hal yang berkaitan dengan permasalahan masyarakat setempat.Hal itu diakui oleh Erik Maulana (2015), staf Humas Pemkot Malang, yang beberapa kali ikut mendampingi Walikota dalam berbagai kegiatan Sambung Rasa.

Selain itu, pasca penangkapan tiga anggota ISIS, cara-cara persuasif melalui sosialisasi kepada seluruh elemen masyarakat terus digalakkan. Hal itu diimplementasikan dengan dilaksanakannya Sosialisasi Antisipasi Gerakan dan Pengembangan Organisasi Radikal/ISIS di level kelurahan (Noermawan 2015). Sosialisasi tersebut mengundang seluruh pengurus RT, RW, tokoh agama, dan tokoh masyarakat. Tujuannya adalah untuk memberikan gambaran dan pemahaman kepada 
masyarakat terkait ISIS dan bagaimana mengantisipasi lingkungan masing-masing dari kemungkinan potensi jaringan ISIS.

Dalam kegiatan sosialisasi yang sempat diikuti peneliti, para pembicara menekankan perlunya petugas RT/RW untuk mencatat dan mengadministrasikan setiap penduduk yang datang (masuk) atau pergi (keluar) dari lingkungannya. Setiap perpindahan penduduk, RT/RW harus selektif dengan menanyakan surat keterangan pindah, meminta identitas, dan mencatat informasi-informasi dari yang bersangkutan. Mereka yang kemudian tidak dapat menunjukkan kartu identitasnya, maka Ketua RT/RW diberi kewenangan untuk menegur dan melaporkan kepada aparat.

Akan tetapi, kegiatan tersebut masih bersifat parsial dan tidak menyeluruh. Hingga tulisan ini ditulis, hanya Kecamatan Klojen dan Sukun yang melakukan sosialisasi formal seperti diuraikan di atas. Adapun kegiatan sosialisasi di kecamatan lain lebih berlangsung informal dalam bentuk Cangkrukan. Selain itu, jadwal yang telah disusun tidak berjalan sebagaimana mestinya. Hal itu dibuktikan dengan pengalaman peneliti di lapangan yang berusaha menghadiri kegiatan sebagaimana terjadwal, yakni pada 20 dan 21 April 2015. Namun, kegiatan batal digelar dan berdasarkan konfirmasi ke Bakesbangpol pada 15 Mei 2015 kegiatan pengganti belum digelar.

Terkait Cangkrukan, kegiatan tersebut merupakan agenda rutin Forum Pimpindan Daerah (Forpimda), yang meliputi Pemkot bersama instansi samping Kepolisian dan TNI, untuk menghimpun aspirasi masyarakat dan sekaligus memberikan sosialisasi terkait keamanan dan ketertiban masyarakat. Pada kecamatan selain Klojen dan Sukun, upaya sosialisasi antisipasi ISIS dilakukan melalui momentum Cangkrukan antara warga dan unsur Forkompida, salah satunya di Kelurahan Dinoyo, Kecamatan Lowokwaru. Dalam kegiatan itu, dibahas upaya antisipasi berkembangnya paham ISIS dan juga hal-hal yang berpotensi mengancam keamanan dan ketertiban masyarakat, seperti pencurian. Bagi Pemkot Malang, sebagaimana ditegaskan Widianto (2015), himbauan, sosialisasi, dan cara-cara persuasif yang dilakukan tersebut diharapkan dapat menggelinding dan membudaya di masyarakat.

Selain daripada itu, pada 9 Mei 2015, stakeholders Kota Malang (Bakesbangpol, Kodim, Kepolisian, dan FKUB) juga juga menggelar pertemuan dengan takmir masjid, tokoh agama, dan agen biro perjalanan terkait upaya antisipasi perkembangan jaringan ISIS (Noermawan 2015).Para takmir masjid dan tokoh agama diminta untuk 
memberi pemahaman kepada masyarakat terkait paham-paham yang berpotensi mengganggu keamanan dan ketertiban masyarakat. Adapun biro perjalanan diminta untuk waspada dan selektif kepada setiap orang yang ingin pergi keluar negeri (Ramadhan 2015). Hal itu merupakan salah satu upaya untuk mempersempit ruang gerak anggota dan jaringan ISIS.

Adapun terkait respons represif, pasca penangkapan pada 25 Maret 2015 hingga batasan waktu penelitian yakni Mei 2015, respons represif berupa penangkapan belum dilakukan kembali. Kendati demikian, Kominda tetap menghimpun informasi terkait gerakan dan aktivitas jaringan ISIS di wilayah Kota Malang. Sebagaimana diungkapkan Noermawan (2015) bahwa selain tiga orang yang telah ditangkap, intelijen yang tergabung dalam Kominda masih terus mengawasi beberapa pihak. Hal yang sama ditegaskan narasumber Intelijen (2015) bahwa kelompok-kelompok yang diidentifikasi sebagai kelompok rentan terus diawasi dan dipantau oleh jaringan intelijen. Pengawasan oleh intelijen ini dapat disebut sebagai bentuk invasif atau proaktif.

\section{Security Governance dalam Merespons ISIS}

Ancaman ISIS di Kota Malang tentu tidak bisa dihadapi sendiri oleh aparat Pemkot. Butuh sinergitas dan kerja sama antara berbagai aktor dalam merespons ancaman ISIS sehingga membutuhkan security governance. Security governance merujuk pada integrasi antara aktor publik (pemerintah) dan aktor privat untuk menciptakan keamanan dalam konteks dan dimensi yang lebih luas (Daase dan Friesendolf 2010).

Dalam security governance, terdapat tiga model yang dapat dilakukan (National Institute of Standards and Technology 2011). Pertama, pendekatan sentralisasi (centralized approach),merujuk pada pemusatan wewenang, tanggung jawab, dan pengambilan keputusan pada pemerintah di top level. Kedua, pendekatan desentralisasi (decentralized approach), merujuk pada pendelegasian wewenang, tanggung jawab, dan pengambilan keputusan kepada para stakeholders untuk menentukan sendiri kebijakan dan prosedur yang perlu dilakukan. Ketiga, pendekatan campuran (hybrid approach), wewenang, tanggung jawab, dan pengambilan keputusan didistribusikan antara pemerintah (aktor publik) dan non-pemerintah (aktor privat). 
Adapun model security governance yang dipraktikkan adalah model hybrid, dengan adanya share kewenangan dan tanggung jawab antara pemerintah (aktor publik) dengan aktor non-pemerintah (aktor privat) terkait tentang tindakan yang perlu dilakukan. Dalam konteks ini, keterlibatan aktor publik (pemerintah dan aparatur negara) dan aktor privat (non-pemerintah) menjadi penting dalam upaya merespons isu dan ancaman ISIS yang berkembang. Implementasinya dibuktikan dari respons Pemkot Malang yang melibatkan aktor publik yakni jajaran instansi samping (TNI, Kepolisian, dan Kemenag)dan aktor privat seperti FKUB, MUI, NU, dan Muhammadiyah. Termasuk juga menggandeng stakeholders perguruan tinggi dalam upaya menghadapi ancaman ISIS.

Serangkaian respons yang telah diuraikan di atas juga menunjukkan bahwa dalam merespons isu dan ancaman ISIS, pendekatan yang dilakukan oleh Pemkot Malang mencakup multiple and multilevel actors. Multiple actors ditunjukkan dengan terlibatnya beragam aktor, baik aktor publik dan aktor privat. Multilevel actors ditunjukkan dengan terlibatnya jajaran aktor di berbagai level mulai dari level kecamatan, kelurahan, hingga RT/RW. Adapun wewenang dan tanggung jawab dari serangkaian bentuk respons tersebut tidak semata terpusat pada Pemkot Malang yang berada di top level, melainkan didistribusikan antara pemerintah dan para stakeholders sesuai dengan proporsi yang dimiliki masing-masing aktor.

Sebagaimana kerangka pendekatan hybrid dalam security governance, terjadi share kewenangan dan tanggung jawab antara aktor publik dengan aktor privat. Dalam konteks ini, Pemkot Malang menegaskan perlunya upaya pendekatan persuasif yang selanjutnya dieksekusi oleh jajaran pemerintah di level kecamatan dan kelurahan dengan melibatkan aktor lain seperti TNI, Kepolisian, FKUB, MUI serta diimplementasikan oleh pengurus RT/RW. Kemudian, jajaran TNI dan Kepolisian bergerak pula sesuai dengan tugas dan tanggung jawabnya namun tidak terlepas dari hubungan koordinatif dengan Pemkot. Begitupula ormas seperti NU dan Muhammadiyah bergerak sesuai dengan porsi fungsinya namun dengan tetap memiliki hubungan komunikasi dengan Pemkot dan aktor lainnya. Adapun di kalangan perguruan tinggi, salah satunya diimplementasikan dengan digelarnya Sarasehan dan Deklarasi Bersama Lima Pilar Keamanan dan Ketertiban Masyarakat di UIN Maulana Malik Ibrahim Malang pada 29 April 2015. 
Lima pilar Kamtibmas yang dimaksud adalah TNI, Polri, Pemda, akademisi, dan tokoh agama (Zainuddin 2015).

Dengan demikian, mekanisme koordinasi yang berlangsung bersifat network coordination atau integrated approach. Network coordination tersebut melibatkan local multi-agency (aktor publik dan aktor privat) melalui hubungan koordinatif strategic partnerships(Mantiono 2007). Hal ini sejalan dengan konsepsi local governance bahwa ada hal-hal yang tidak bisa ditangani dan diselesaikan sendiri oleh pemerintah lokal (aktor publik) sehingga menuntut perlunya keterlibatan dan sinergitas dengan aktor privat untuk goes hand by hand dalam menghadapinya (Shah 2010), isu dan ancaman ISIS adalah salah satu contohnya.

\section{Respons Pemkot Malang dalam Konteks Respons Negara dan Global}

Serangkaian respons berupa Deklarasi Penolakan Keberadaan ISIS; mengumpulkan para Ketua RT/RW, tokoh masyarakat, serta tokoh agama; menggelar sosialisasi secara formal dan informal kepada masyarakat; blusukan dalam bentuk Sambung Rasa, Cangkrukan; dan kegiatan lainnya menunjukkan adanya kecenderungan bahwa Pemkot Malang mengutamakan pendekatan persuasif dalam merespons ancaman ISIS. Adapun pendekatan represif lebih merupakan tindak lanjut dari proses pendalaman informasi yang dilakukan oleh intelijen hanya jika memenuhi unsur pelanggaran hukum.

Dapat dipahami bahwa pendekatan persuasif diutamakan karena ancaman ISIS bersifat non-fisikmelalui penyebaran doktrin dan ideologi. Ditambah lagi narasi-narasi jihad dan bahasa agama versi mereka dikemas melalui instrumen internet dan media sosial. Akibatnya, tidak mudah untuk mengungkap pergerakan jaringannya di lapangan. Diakui pula oleh Intelijen (2015), bahwa jaringan ISIS, dan kelompok teroris pada umumnya, bersifat sel terputus. Artinya, ada kemungkinan sesama jaringan tidak saling mengenal sehingga sulit untuk melacak keterkaitan di antara mereka. Karena itulah, pendekatan persuasif dibutuhkan dalam upaya membentengi pengetahuan dan pemahaman masyarakat untuk tidak mudah terpengaruh oleh doktrindoktrin jihad ala ISIS.

Serangkaian respons yang diuraikan di atas menunjukkan bahwa setidaknya Pemkot Malang, dalam merespons ancaman ISIS, sinergis 
dengan Pemprov Jatim dan pemerintah pusat. Respons Pemkot Malang tersebut sejalan dengan Pergub Jatim 51/2014 tentang Larangan Keberadaan Gerakan ISIS di Jawa Timur. Menurut penuturan Noermawan (2015), Pergub itu kemudian menjadi dasar hukum dari pelarangan ISIS di Kota Malang dan segala langkah yang dilakukan Pemkot Malang.Kebijakan merespons ISIS yang dilakukan jajaran Pemkot Malang merupakan tindak lanjut dari Pergub dan instruksi gubernur ditambah dengan usaha-usaha lain yang sejalan dengan itu (Noermawan 2015; Widianto 2015).

Respons persuasif Pemkot Malang melalui beragam sosialisasi pasca penangkapan tiga orang tersangka anggota ISIS di Kota Malang juga membuktikan sinergitas tersebut. Pasca penangkapan tanggal 25 Maret 2015, Gubernur Jatim mengeluarkan surat edaran tertanggal 27 Maret 2015 yang ditujukan kepada seluruh bupati/walikota se-Jawa Timur mengenai perlunya upaya deteksi dini dan antisipasi ancaman gangguan keamanan, ketenteraman, dan ketertiban di wilayah Jatim dari pengembangan ISIS. Sosialisasi yang dilakukan jajaran Pemkot Malang dengan menggandeng para stakeholders kemudian dapat dipahami sebagai implementasi dan tindak lanjut dari instruksi dalam edaran itu.

Selain itu, respons Pemkot Malang serta Pemprov Jatim juga menunjukkan sinergitas dengan pemerintah pusat. Setelah pemerintah Indonesia (era SBY) menyatakan sikap resmi terkait pelarangan ISIS di Indonesia, Menteri Dalam Negeri kemudian mengeluarkan surat edaran yang ditujukan kepada gubernur, bupati, dan walikota di seluruh daerah dan juga ditembuskan kepada Kepala Bakesbangpol provinsi dan kabupaten/kota di Indonesia.

Sinergitas respons Pemkot Malang dan Pemprov Jatim dengan pemerintah pusat sejalan pula dengan arah kebijakan dan komitmen pemerintahan Joko Widodo. Presiden Joko Widodo menyatakan bahwa Indonesia memiliki pendekatan keagamaan (religion approach) dan pendekatan budaya (cultural approach) dalam menyikapi ISIS (Sa'diyah 2014; Lumanaw 2014), yang kemudian dapat dirangkum sebagai pendekatan persuasif. Indonesia menolak ajakan masyarakat internasional untuk memerangi ISIS dengan cara kekerasan dan menggunakan pendekatan keamanan (security approach).

Namun demikian, pendekatan persuasif tersebut tidak meniadakan tindakan represif. Pendekatan represif berupa penangkapan dilakukan jika terdapat unsur pidana, seperti terbukti pernah ke Irak atau Suriah dan bergabung dengan ISIS. Disebut memenuhi unsur pidana karena 
tindakan tersebut merupakan bentuk makar atau pengkhianatan terhadap negara (Atmasasmita 2014).

Logika mengenai perlunya merespons dengan mengutamakan upaya persuasif karena landscape terorisme telah berubah secara signifikan yang juga mempengaruhi perubahan upaya counterterrorism (Fink 2014). Pasalnya, ISIS merupakan bentuk baru dari ancaman terorisme dibanding serangkaian ancaman terorisme yang dihadapi Indonesia terutama sejak 2001. Hal yang sama dikatakan Kagan etal. (2014), bahwa "ISIS is unlikely to lose the will to fight because it is an ideological enemy. Defeating ISIS therefore requires rendering it incapable of fighting."

Serangkaian bentuk pendekatan persuasif yang telah dikemukakan menunjukkan bahwa dalam konteks Indonesia, pemerintah merespons ISIS dengan the whole-of-government approach, yakni dengan keterlibatanaktordi semua level pemerintahan, mulai dari RT/RW, kelurahan, kecamatan, kota, provinsi, hingga pusat (Christensen dan Legreid 2006). The whole-of-government approach dan kecenderungan untuk mengedepankan pendekatan persuasif selanjutnya dapat disebut parallel. Hal itu karena aktor di semua level pemerintahan terlibat, bukan sekadar keterlibatan langsung aparatur negara seperti Kepolisian, TNI, dan Densus 88 yang justru lebih mengutamakan kekuatan koersif atau represif.

Pemerintah pusat menyatakan sikap bahwa ISIS dilarang karena bertentangan dengan ideologi NKRI dan mengeluarkan instruksi untuk mengantisipasi perkembangannya. Pemprov (Jatim) mengeluarkan peraturan sebagai landasan legal-formal dari pelarangan keberadaan ISIS di daerah. Pemkot (Malang) menindaklanjuti dengan berbagai bentuk upaya persuasif, salah satunya dengan sosialisasi yang digelar oleh pemerintah kecamatan dan kelurahan. Kemudian, aparat RT/RW juga mengimplementasikan upaya-upaya antisipasi ancaman ISIS tersebut di lingkungannya masing-masing.

Dalam konteks global, sikap dan respons yang ditunjukkan oleh Indonesia di atas mengambil posisi berbeda dengan respons yang ditunjukkan beberapa negara yang tergabung dalam koalisi internasional melawan ISIS. Indonesia menolak menghadapi ISIS dengan cara koersif atau kekuatan militer, sementara koalisi global untuk memerangi ISIS (global coalition to degrade and defeat ISIS) melakukan serangan militer untuk menumpas eksistensi ISIS. Hingga Desember 2014, ada 62 negara yang bergabung dan mendukung langkah 
militeristik koalisi yang dipimpin oleh AS tersebut (Payne 2014). Hingga tulisan ini dibuat, serangan militer terhadap ISIS masih dilancarkan.

Selain dari pada itu, respons pemerintah Indonesia yang lebih mengutamakan pendekatan soft dan dengan tidak atau belum mengeluarkan landasan hukum berupa undang-undang untuk merespons ISIS menunjukkan posisi yang berbeda dengan negara Asia Tenggara lain, seperti Malaysia, Myanmar, dan Singapura (Chan 2015a; Bashar 2015; Chan 2015b; Yong 2014). Namun demikian, apa yang ditunjukkan oleh Indonesia sesungguhnya dapat disebut sejalan dengan Resolusi Dewan Keamanan (DK) PBB 2170 yang memerintahkan kepada negara-negara anggotanya agar melarang warga mereka melakukan perjalanan untuk bergabung dengan ISIS.

Selain itu, DK PBB juga mengeluarkan Resolusi 2178. Resolusi tersebut menuntut upaya pencegahan perjalanan dan dukungan bagi foreign terrorist fighters. Indonesia menjadi pendukung dari kedua resolusi tersebut karena dipandang sejalan dengan pandangan Indonesia. Dua resolusi tersebut menekankan bahwa upaya pemberantasan ISIS harus sesuai dengan Piagam PBB, dengan tidak menggunakan pendekatan kekerasan dalam mengatasi akar permasalahan.

Namun, sekalipun berbagai negara menunjukkan sikap dan respons berbeda terhadap ISIS, namun muaranya adalah kombinasi cara, instrumen, dan upaya-upaya secara soft dan militeristik (hard) dimaksudkan untuk menumpas ISIS. Hal ini menunjukkan bahwa dalam merespons dan menyikapi ancaman terorisme global ISIS, masyarakat internasional bergerak secara bersama-sama melalui comprehensive approach karena ISIS merupakan ancaman global yang tidak bisa dihadapi hanya dengan satu cara dan hanya oleh satu aktor.Kendati demikian, Indonesia tetap memandang bahwa penggunaan kekuatan militer semata tidak mampu membendung eksistensi ISIS. Karenanya, sinergitas aktor publik dan aktor privat di Indonesia diintegrasikan melalui kerangka public-private partnership dalam local governance.

Dengan demikian, dapat dipahami bahwa respons Pemkot Malang sinergis dengan pandangan pemerintah Indonesia terkait ISIS. Serta, pandangan Indonesia untuk mengedepankan pendekatan non-militer (pendekatan kultural) sejalan dengan prinsip yang tertuang dalam Resolusi dan Piagam PBB. Dalam konteks Kota Malang, mengutamakan pendekatan persuasif (non-militer) tidak terlepas dari konteks antropologis dan kultural Kota Malang. Menurut Kabag Humas Pemkot 
Malang Nur Widianto, masyarakat Kota Malang memiliki keguyuban yang cukup kuat sehingga budaya komunikasi antar warga lebih aktif melalui beragam aktivitas sosial kemasyarakatan, yang selanjutnya mendukungan upaya-upaya persuasif. Perlunya komunikasi antar masyarakat dan penguatan keguyuban, menurut Widianto (2015), karena pola-pola menutup diri menjadi resistan bagi masuknya pahampaham yang bertentangan dengan ideologi bangsa dan ajaran agama.

Selain itu, menurut Ketua FKUB Kota Malang Sudjoko Santoso, Kota Malang menempati peringkat pertama di Jawa Timur dalam hal kerukunan antar umat beragama, namun dalam hal konflik internal agama berada pada peringkat 35 dari 38 daerah di Jawa Timur. Data FKUB menyebutkan bahwa dari total jumlah penduduk Kota Malang yang mencapai sekitar 850 ribu jiwa, 88,93 persen di antaranya adalah umat Islam, 9,40 persen Katolik-Protestan, dan sisanya 1,67 persen adalah pemeluk Hindu, Buddha, Konghucu, dan kepercayaan lain (Santoso 2015). Dengan data tersebut, maka mengedepankan pendekatan persuasif menjadi penting guna memberikan pemahaman kepada masyarakat terkait paham dan gerakan yang berpotensi memecah kerukunan beragama dan antar umat seagama.

\section{Simpulan}

Respons Pemkot Malang terhadap ancaman ISIS dapat dikategorikan ke dalam pendekatan persuasif dan represif. Pendekatan persuasif antara lain melalui deklarasi penolakan keberadaan ISIS dan sosialisasi kepada masyarakat agar berperan aktif mengantisipasi perluasan dan perkembangan ISIS. Adapun pendekatan represif dilakukan melalui penangkapan tiga anggota ISIS pada 25 Maret 2015. Adanya penangkapan tersebut menjadikan Pemkot Malang semakin proaktif melakukan berbagai upaya persuasif untuk membentengi dan memberikan pemahaman kepada masyarakat untuk tidak terpengaruh dengan doktrin dan ideologi ISIS. Berbagai respons dan upaya yang dilakukan selanjutnya menunjukkan bahwa Pemkot Malang mengutamakan pendekatan persuasif, apalagi karena ancaman ISIS lebih didefinisikan sebagai ancaman non-fisik (ideologis).

Dalam merespons ancaman ISIS di Kota Malang, aktor publik dan aktor privat dapat dikatakan berjalan sinergis. Hal tersebut menunjukkan implementasi dari model hybrid security governance dan local governance. Selain itu, juga mencakup multi-level agency, yakni dengan 
memberikan kewenangan kepada aparat RT/RW, kelurahan, dan kecamatan untuk melakukan upaya-upaya antisipatif penyebaran paham dan perkembangan jaringan ISIS.Peran aktor di level RT/RW dan kelurahan dipandang penting dan memiliki peran yang besar karena bersentuhan secara langsung dengan masyarakat grass-rootsehingga memungkinkan serangkaian upaya persuasif yang dilakukan dapat efektif.

Serangkaian respons yang ditunjukkan oleh Pemkot Malang menunjukkan adanya sinergitas dengan Pemprov Jatim dan pemerintah pusat dalam merespons dan menyikapi ancaman ISIS. Sinergitas tersebut juga terbangun dengan keterlibatan aparat pemerintah (aktor publik) di seluruh level mulai dari RT/RW, kelurahan, kecamatan, kota, provinsi, hingga pusat dalam merespons ISIS. Hal itu menggambarkan the whole-of-government approach mengenai keterlibatan pemerintah di semua level dalam merespons isu ISIS. Selanjutnya, dalam konteks Kota Malang respons dan serangkaian upaya yang dilakukan tidak terlepas dari karakteristik sosial masyarakat Kota Malang.

Kajian ini sekaligus mengisi keterbatasan kajian yang dikemukakan sebelumnya bahwa dalam kajian terdahulu yang ditemukan terkait bagaimana merespons ISIS lebih banyak difokuskan pada level sistem internasional, regional/multilateral, dan negara. Hal ini sekaligus menunjukkan bagaimana isu-isu internasional berpengaruh dan direspons di level lokal suatu negara, sejalan dengan konsepsi intermesticdalam studi HI.

\section{Daftar Pustaka}

\section{Buku}

Al-Makassary,Ridwan, 2003.Terorisme Berjubah Agama. Jakarta: Pusat Bahasa dan Budaya UIN Syarif Hidayatullah Jakarta dan Konrad Adenauer Stiftung.

Daase, Christopher, dan Cornelius Friesendorf (eds.), 2010. Rethinking Security Governance: The Problem of UnintendedConsequences. New York: Routledge.

Hidayat, Komaruddin (ed.),2014. Kontroversi Khilafah: Islam, Negara, dan Pancasila. Jakarta: Mizan.

Mashuri,Ikhwanul Kiram,2014. ISIS Jihad atau Petualangan. Jakarta: Republika. 
Shah, Anwar (ed.), 2006.Local Governance in Developing Countries. Washington DC.: The World Bank.

Wahid, Abdurrahman (ed.),2009. Ilusi Negara Islam: Ekspansi Gerakan Islam Transnasional di Indonesia. Jakarta: LibForAll Foundation.

ZTF, Pradana Boy, 2008. Fikih Jalan Tengah: Dialektika Hukum Islam dan Masalah-Masalah Masyarakat Modern. Jakarta: Hamdalah.

\section{Jurnal}

Bashar, Iftekharul, 2015. "Southeast Asia: Myanmar",Counter Terroris Trends and Analysis, January/February, 7 (1): 17-20.

Chan, Anton,2015a."Southeast Asia: Malaysia",Counter Terroris Trends and Analysis, January/February, 7 (1): 13-16.

Chan, Anton, 2015b. "Souhteast Asia: Singapore," Counter Terroris Trends and Analysis, January/February, 7 (1): 28-29.

Fink, Naureen Chowdhury, 2014. "Countering Terrorism and Violent Extremism: The Role of the United Nations Today and the Impact of Security Council Resolution 2178." Global Center on Cooperative Security, November.

\section{Working Papers}

Christensen, Tom, dan Per Legreid, 2006. "The Whole-of-Government Approach-Regulation, Performance, and Public-Sector Reform”,Stein Rokkan Centre for Social Studies, Working Paper 6, August.

Friedland,Elliot, 2014. "Special Report: The Islamic State",The Clarion Project, November.

Kagan, Kimberly, et al., 2014. "A Strategy to Defeat the Islamic State",Middle East Security Report 23, Institute for the Study of War, September.

Mantino, Franco, 2007. "Typologies of Governance Models",Assessing the Impact of Rural Development Policies, National Institute of Agricultural Economics, Rome, Italy.

Organization of Islamic Cooperation, 2015. "Islamic Response to the Islamic State of Iraq and the Levant",MISH Model United Nations.

The Meir Amit Intellegence and Terrorism Information Center, 2014. "ISIS: Potrait of a Jihadi Terroris Organization", November. 


\section{Artikel Online}

Atmasasmita, Romli, 2014. "ISIS Masalah Bagi Indonesia?" [online]. dalam http://nasional.sindonews.com/read/888991/18/isismasalah-bagi-indonesia-1407400079 [diakses 23/05/2015].

Berger, J. M, 2014. "How ISIS Games Twitter" [online]. dalam http://www.theatlantic.com/international/archive/2014/o6/isisiraq-twitter-social-media-strategy/372856/ [diakses 04/10/2014].

Hadi, Samsul, 2015. "Perketat Lalu Lalang Penghuni Kos dengan Wajib KTP”

[online]. dalamhttp://suryamalang.tribunnews.com/2015/03/27/perketatlalu-lalang-penghuni-kos-dengan-wajib-ktp[diakses 01/o5/2015].

Jatimprov, 2014. "Cegah ISIS, Polda Jatim Pantau Tujuh Titik" [online]. dalamhttp://www.jatimprov.go.id/site/cegah-isis-polda-jatimpantau-tujuh-titik/[diakses 14/02/2015].

Kuwado, Fabian Januarius, 2015. "ISIS Bukan Barang Baru di Indonesia" [online]. dalam http://nasional.kompas.com/read/2015/03/31/19311411/.ISIS.Buk an.Barang.Baru.di.Indonesia[diakses 13/04/2015].

Lumanaw, Novy, 2014. "SBY: ISIS Terapkan Ideologi Eksklusif Antidemokrasi" [online]. dalam http://www.beritasatu.com/nasional/216413-sby-isis-terapkanideologi-eksklusif-antidemokrasi.html[diakses 14/02/2015].

Martel,Frances, 2014. "Indonesia Criminalizes Support for ISIS" [online].dalam http://www.breitbart.com/nationalsecurity/2014/o8/o6/indonesia-criminalizes-support-forisis/[diakses pada 11/02/2015].

Payne, Sebastian, 2014. "What the 60-plus members of the anti-Islamic State coalition are doing" [online]. dalam http://www.washingtonpost.com/news/checkpoint/wp/2014/o9/2 5/what-the-60-members-of-the-anti-islamic-state-coalition-aredoing/ [diakses 29/05/2015].

Prabowo, Dani, 2015a. "BNPT: ISIS Berlindung di Balik Simbol Langit, Padahal Radikal" [online]. dalam http://nasional.kompas.com/read/2015/o3/19/15273091/BNPT.ISI S.Berlindung.di.Balik.Simbol.Langit.Padahal.Radikal[diakses 13/04/2015]. 
Prabowo, Dani,2015b. "Mantan Wakil Kepala BIN Sebut ISIS Punya Jaringan Baru di Indonesia”[online]. dalamhttp://nasional.kompas.com/read/2015/o3/22/14022091/M antan.Wakil.Kepala.BIN.Sebut.ISIS.Punya.Jaringan.Baru.di.Indone sia[diakses 13/04/2015].

Ramadhan, Bilal, 2015. "Jaringan ISIS di Indonesia Tak Banyak tetapi Meresahkan" [online]. dalamhttp://www.republika.co.id/berita/nasional/hukum/15/05/1 o/no3gyo-jaringan-isis-di-indonesia-tak-banyak-tapi-sangatmeresahkan [diakses 22/05/2015].

Sa'diyah, Halimatus, 2014. "Jokowi Tolak Perangi ISIS dengan Cara Kekerasan" [online]. dalam http://www.republika.co.id/berita/internasional/global/14/11/13/n ez6ke-jokowi-tolak-perangi-isis-dengan-cara-kekerasan[diakses 14/02/2015].

Sudarmojo, Slamet, 2014. "Jawa Timur Rawan Penyebaran ISIS" [online]. dalam http://www.antaranews.com/berita/451951/jawatimur-rawan-penyebaran-isis [diakses 14/02/2015].

Yong, Charissa, 2014. "Parliament: Singapore will contribute personnel and equipment to multinational coalition against ISIS" [online]. dalam http://news.asiaone.com/news/singapore/parliamentsingapore-will-contribute-personnel-and-equipment-multinationalcoalition [diakses 31/05/2015].

\section{Publikasi Resmi}

Peraturan Gubernur Jawa Timur Nomor 51 Tahun 2014 tentang Larangan Keberadaan Gerakan Islamic State of Iraq and Syria di Jawa Timur, 2014. Surabaya: Pemprov Jatim

Surat Edaran Menteri Dalam Negeri Republik Indonesia Nomor 450/3806/SJ Tanggal 7 Agustus 2014 Perihal Peran Akif Kepala Daerah dalam Penanganan Penyebaran Paham dan Ideologi ISIS di Indonesia, 2014. Jakarta: Kemendagri

United Nations Security Council, Resolution 2170 (2014), Adopted by the Security Council at its $7242^{\text {nd }}$ meeting, on 15August 2014.

United Nations Security Council, Resolution 2178 (2014), Adopted by the Security Council at its $7272^{\text {nd }}$ meeting, on 24September 2014.

\section{Wawancara}

Wawancara E. M. Sangadji, 18 Mei 2015.

Wawancara Intelijen, 17 April dan 5 Mei 2015.

Wawancara Isroqun Najah, 29 April 2015. 
Wawancara Muhadjir Effendy, 3 Juni 2015.

Wawancara Muhammad Nur Widianto, 14 April 2015.

Wawancara Noor Chozin Askandar, 21 April 2015.

Wawancara Sudjoko Santoso, 27 April 2015.

Wawancara Tony Noermawan, 14, 16 April, dan 15 Mei 2015.

Wawancara Zainuddin, 12 Mei 2015. 